\title{
Effect of Training Interaction and Anger Controlling Skill on Nurses' Exposure to Aggressive Behaviors in Hospitalized Patients in Psychiatric Departments of Selected Military Hospitals
}

\author{
Jafari Samie. $\mathrm{M}^{1}$ \\ ${ }^{*}$ Farsi. $Z^{2}$ \\ Azizi. $\mathrm{M}^{3}$ \\ 1- MSc in Student of Psychiatric \\ Nursing, Faculty of Nursing, \\ Aja University of Medical \\ Sciences, Tehran, Iran. \\ 2- ( ${ }^{*}$ Corresponding Author) \\ Ph.D., in Nursing, Associate \\ Professor, Research \\ and Community Health \\ Department, Faculty of \\ Nursing, Aja University of \\ Medical Sciences, Tehran, \\ Iran. \\ Email: zahrafarsi@gmail.com - \\ z.farsi@ajaums.ac.ir \\ 3- MSc in Psychiatric Nursing, \\ Faculty of Nursing, Aja \\ University of Medical Sciences, \\ Tehran, Iran.
}

\begin{abstract}
Introduction: lacking the interaction and anger controlling skill while facing the aggressive behaviors of neuropsychiatric patients cause stress in nurses..

Objective: The present study investigated the effect of interaction skill training and anger management on nurses' exposure to aggressive behaviors of patients admitted in psychiatric wards of selected military hospitals.
\end{abstract}

Materials and Methods: This quasi-experimental study was a randomized clinical trial conducted in selected hospitals of Aja University of Medical Sciences during the years 2018-2019. Fifty-eight nurses were selected by census method and studied in control and test groups. The teaching materials included lecturing, using PowerPoint and Q\&A in eight sessions. The effect of training anger control and interaction skill before and immediately after the intervention and two months after the intervention was assessed using a standard questionnaire. Data were analyzed by SPSS 20 using independent statistical t-test, Fisher's exact test and Friedman test. Significance level was considered $\mathrm{P}<0.05$.

Results: The result from Fisher exact test in both groups showed no significant difference in terms of reaction to violence before the intervention $(\mathrm{P}>0.05)$, immediately after the intervention $(\mathrm{P}>0.05)$ and eight weeks after the intervention $(\mathrm{P}>0.05)$.

Discussion and and Conclusion: After the intervention, nurses showed a more favorable reaction to aggression than before the intervention, although these changes were not statistically significant. It seems that making a great change in this area requires more prolonged intervention. Thus, it is recommended that training interaction skills and anger controlling be included on the agenda of nursing managers with other training methods. Further studies with a higher sample size are recommended.

Keywords: Aggression, Anger Management, Communication Skill, Nurses, Psychiatry. 


\title{
بررسى تأثير آموزش مهارت ارتباطى و مديريت خشم بر نحوه مواجهه ير ستاران با رفتار هاى

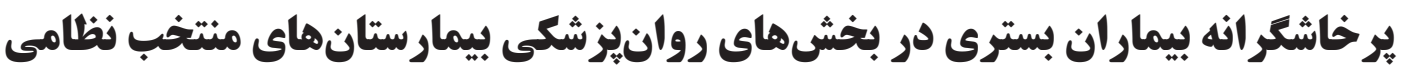

\author{
مريم جعفرى سميع'، "زهر ا فارسى"، مريم عزيزى"
}

جكيده

مقدمه: عدم مهارت ارتباطى مناسب و مديريت خشهم در مواجهه يرخاشكَى بيماران اعصاب و روان منجر به ايجاد تنش در : ترستاران مىشود.

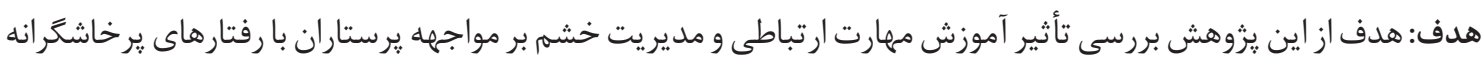
بيماران بسترى در بخشهاى روانيزشكى بيمارستانهاى منتخب نظامى مى بـاشد.

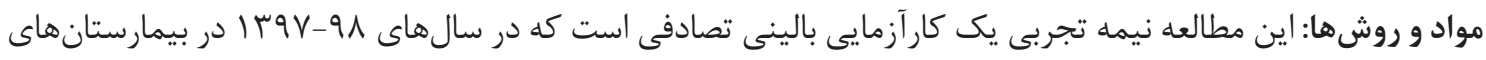

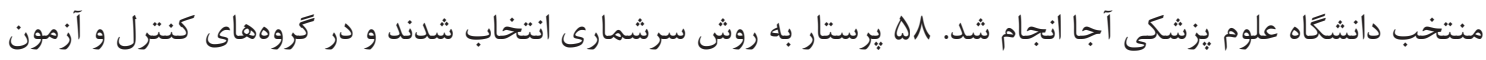

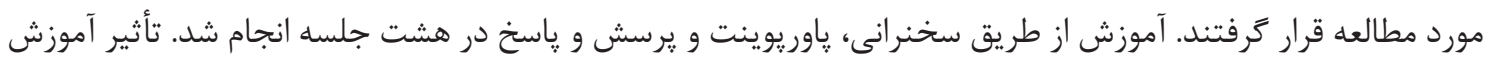

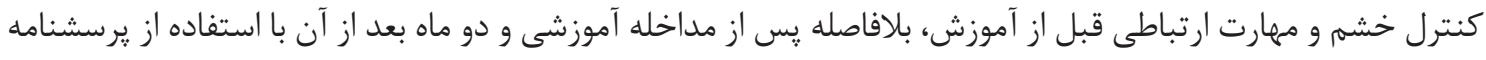

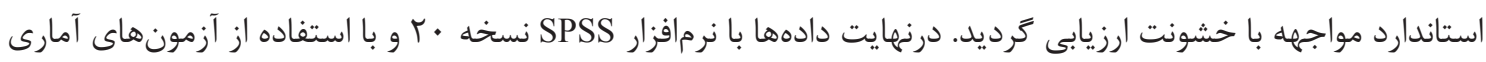

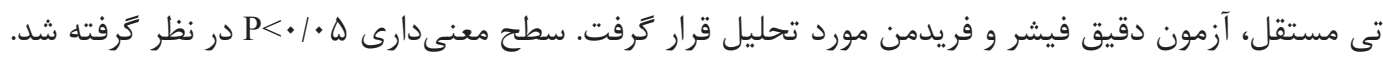

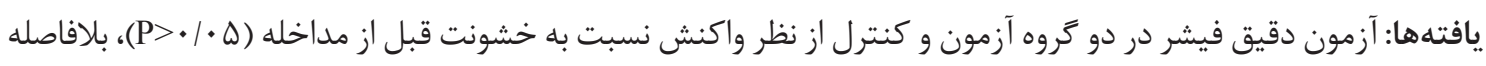

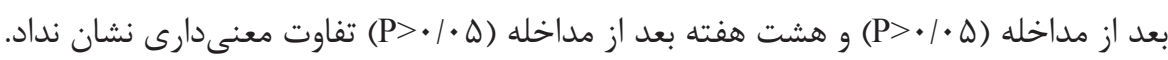

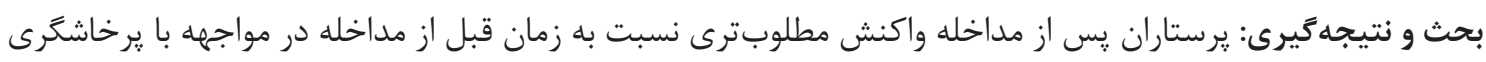

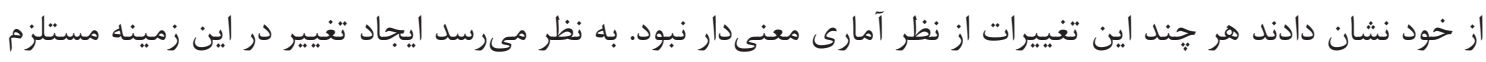

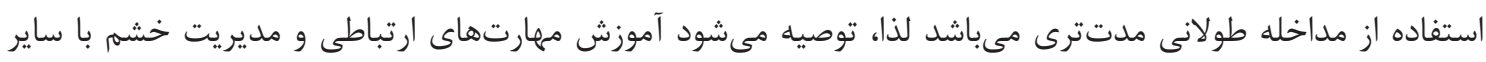

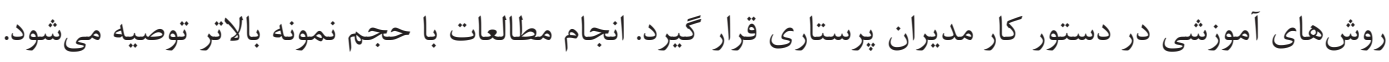

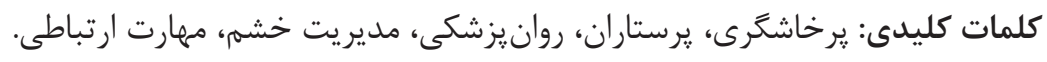

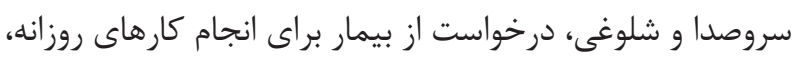

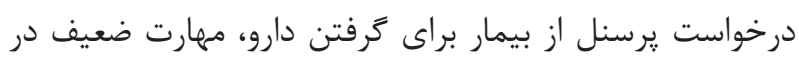

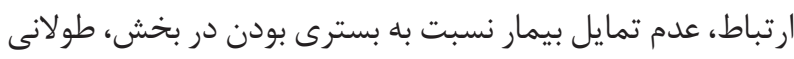

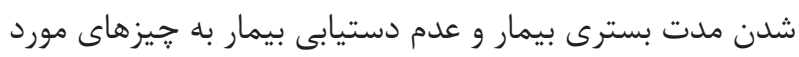

امروزه، يرخاشكَى و عواقب منفى آن بر سلامت، امنيت، رفاه

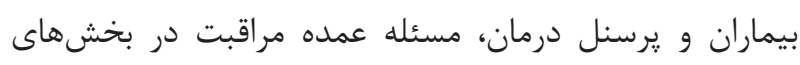

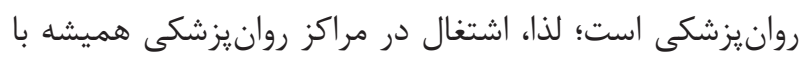

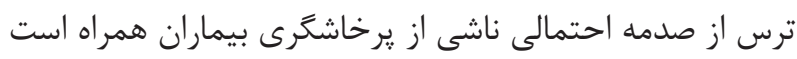


يرستاران علاوه بر داشتن مهارت مديريت خشم بايد در رابطه با

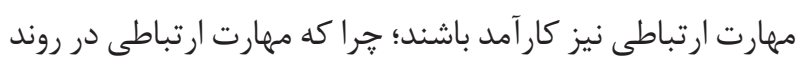

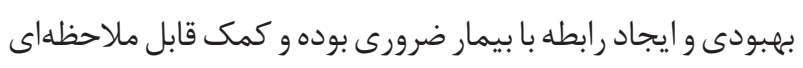
در جهت كاهش تنش ايفا مىنمايد (•) (1. ارتباط مؤثر كليد و

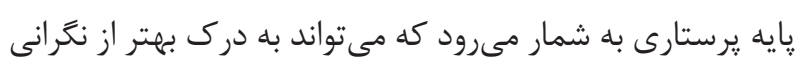

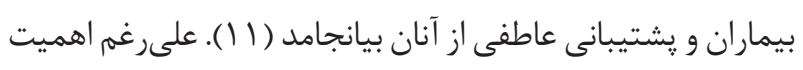

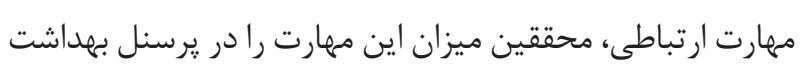

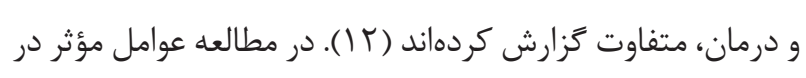

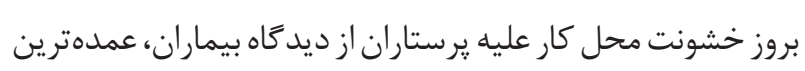

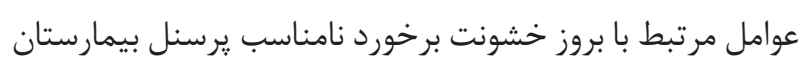

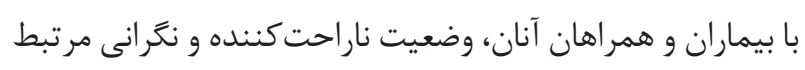

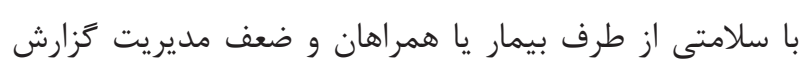

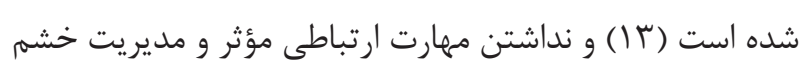

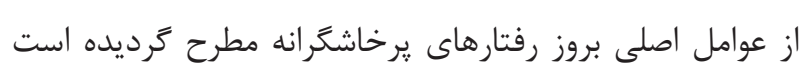

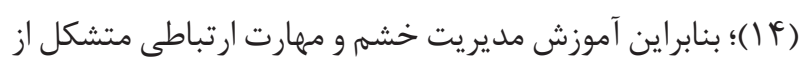
همكارى خوب و ارتباط ميان كاركنان و نظارت مستمر و همدلانه

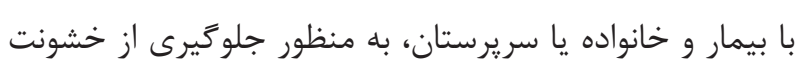

$$
\text { در محل كار امرى ضرورى است (ه) (1). }
$$

طبق بررسى هاى انجام شده در اين زمينه بيشتر مطالعات انجام

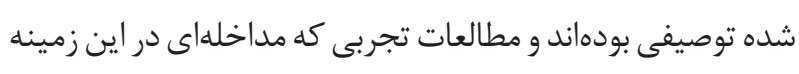
انجام داده باشند، به ندرت انجام شده است (9 (1) . با توجه به اهميت ولديت

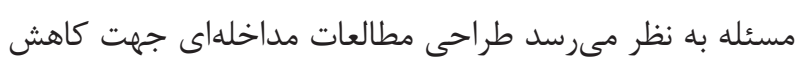

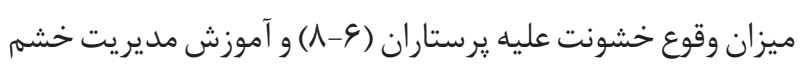

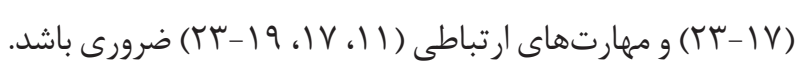

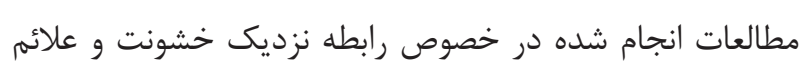

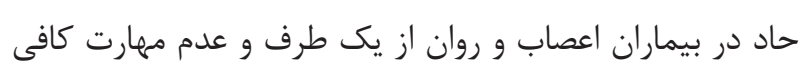
در مديريت خشم و مهارت ارتباطى مناسب يرستاران در زمان

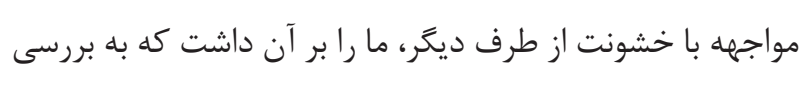

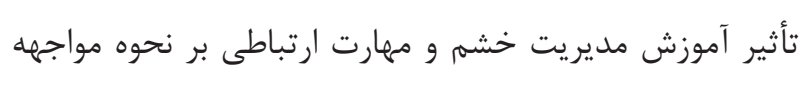

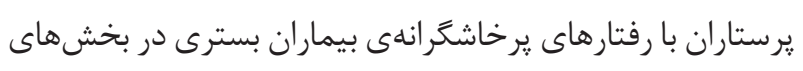
روانيزشكى بيمارستانهاى منتخب نظامى بيردازيم.

\section{مواد و روشها} اين مطالعه نيمه تجربى يك كار آزمايى بالينى تصادفى طى سال هاى
دلخواهش در داخل بخش باعث برانگيختكى و تحريكيذيرى بيمار

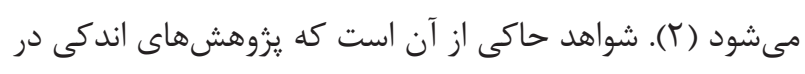

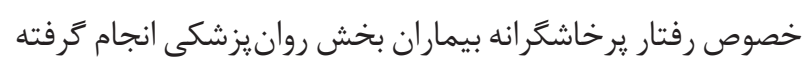

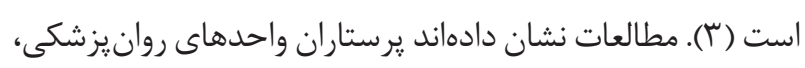
در معرض خطر خشونت كلامى و فيزيكى فراوانى قرار دارند و آمار

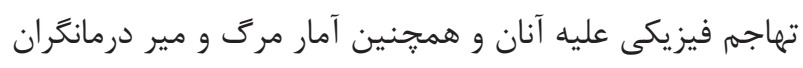

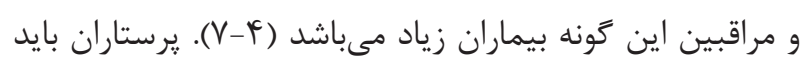

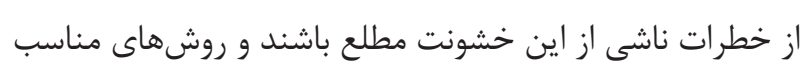

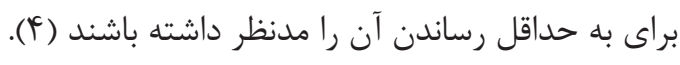

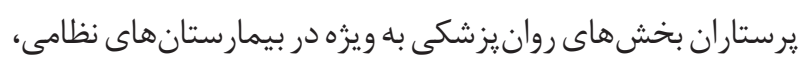

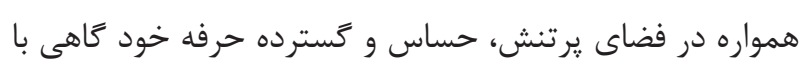

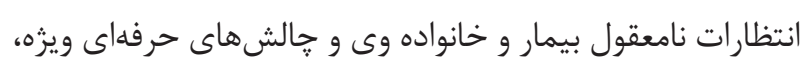

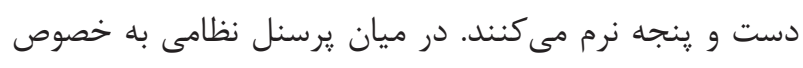

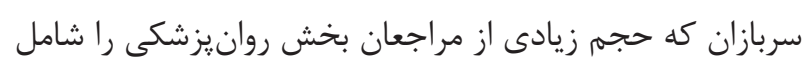

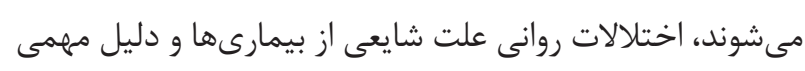

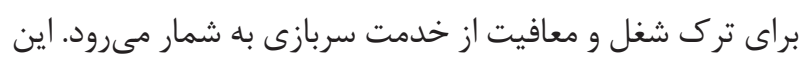

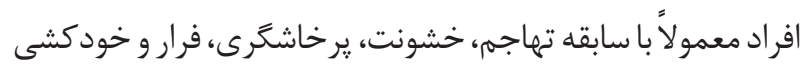

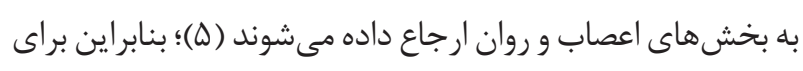
جلوكيرى از جنبه هاى مخرب تجربه خشونتهاى شغلى كه بيشتر

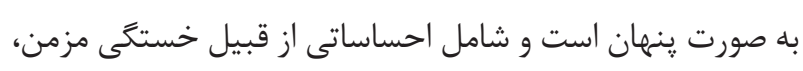

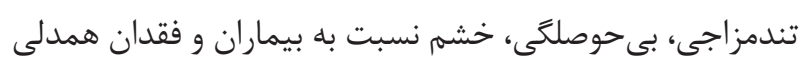
است، توسعه برنامههاى مديريت خشم و توانمندسازى يرستاران

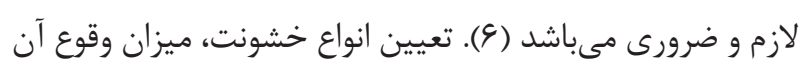

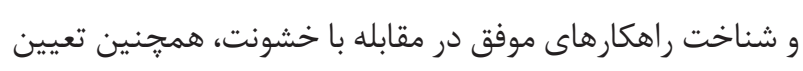
روشهاى مؤثر مديريتى، بيشخيرى، آموزش، بررسى آموختهها،

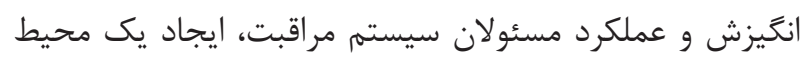

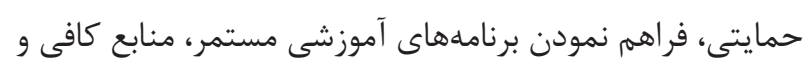

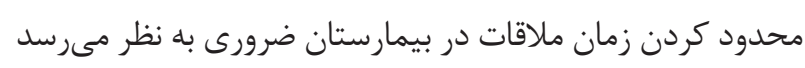

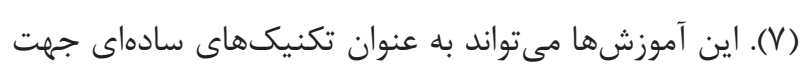
كاستن از تنشهاى كلامى و روش محافظت از خود به كار رود (^). يرستارانى كه در قسمتهاى مختلف بخشهاى روانيزشكى كانى كار

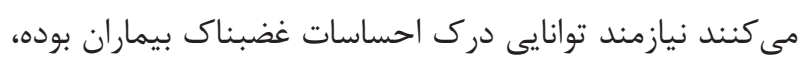

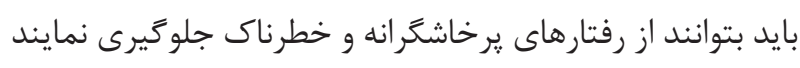
و در موقعيت مناسب از خود واكنش سنجيده نشان دهند (9). 
مورد مطالب آموزش داده شده و تجربيات يرستاران اختصاص داده

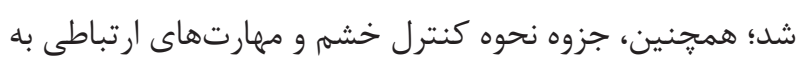

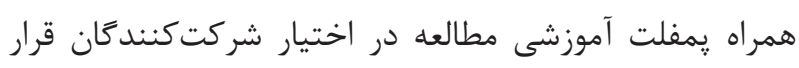

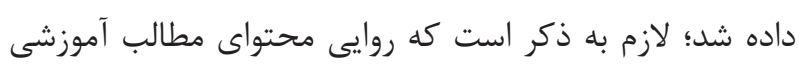

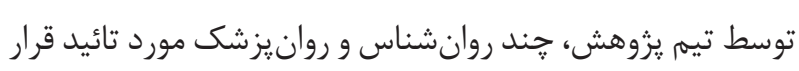

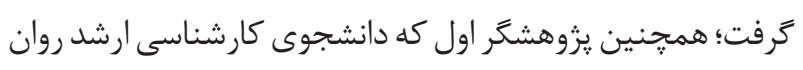

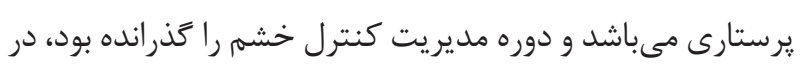
كليه جلسات حضور داشت. شركت كنندكان از نظر ميزان مواجها بها

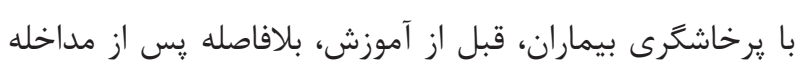

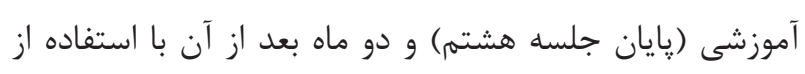

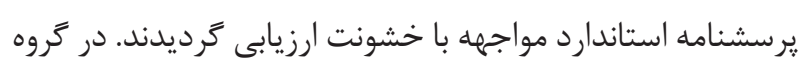

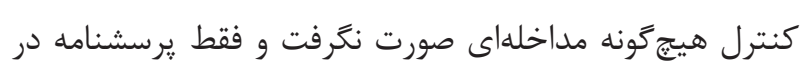

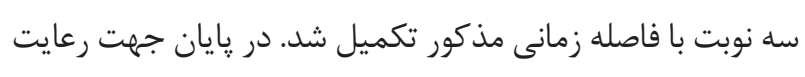

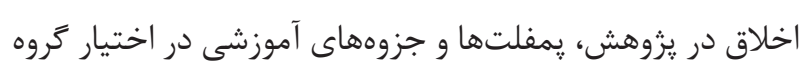

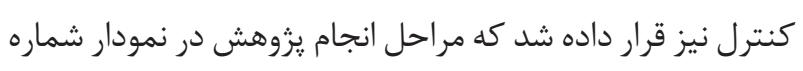
ا نشان داده شده است.

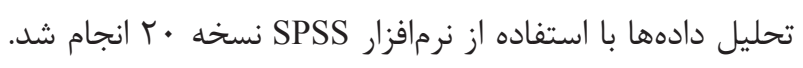

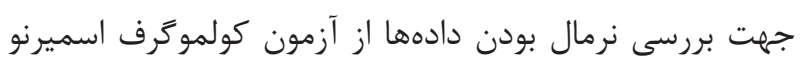

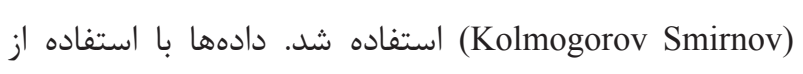
آزمونهاى توصيفى و تحليلى (آزمون تى مستقل، آزمون دقيق

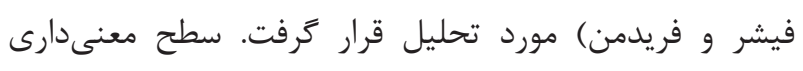

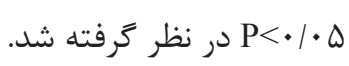

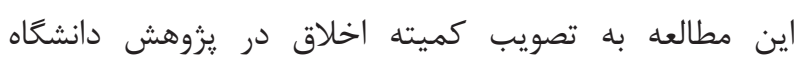

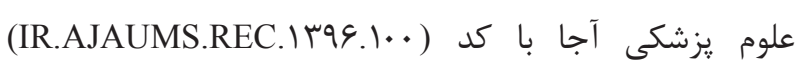

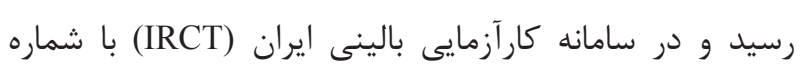

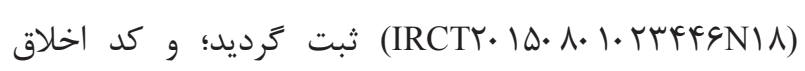
به تصويب رسيده است. در اين مطالعه تمامى مفاد اخلاق در يزوهش مطابق با بيانيه هلسينكى رعايت شد (1) (1). به طور

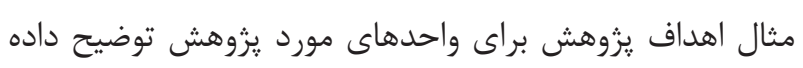
شد، ورود يرستاران به مطالعه داوطلبانه بود و رضايت آحاهانه

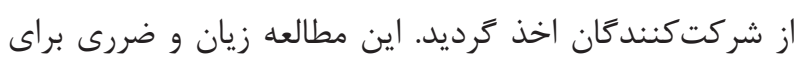
واحدهاى مورد يزوهش نداشت و اطلاعات آنها محرمانه مانده،

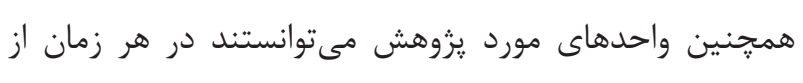

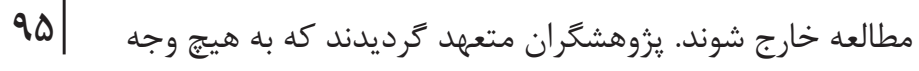



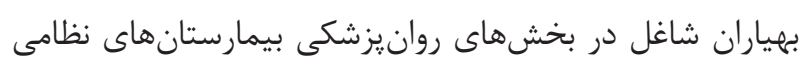
شهر تهران بودند. معيار هاى ورود به مطالعه عبارت بودند از: حداقل

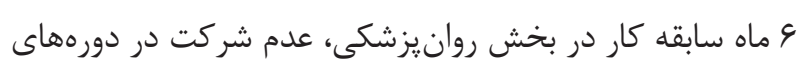

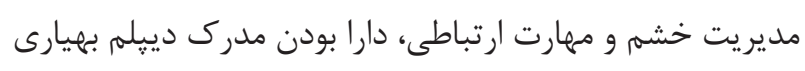

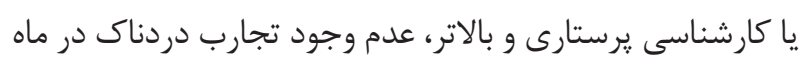
اخير از قبيل فقدان عزيزان، اختلافات خانوادكى و اختلال روانى بـاني ه ه نفر به روش تمام شمارى از دو بيمارستان منتخب دانشعاه

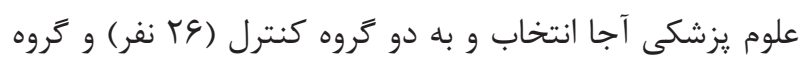

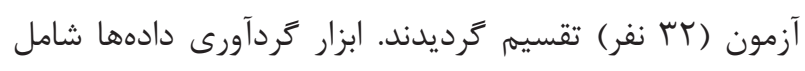

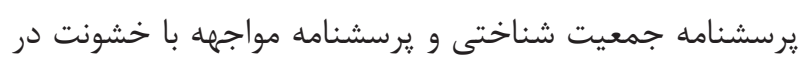

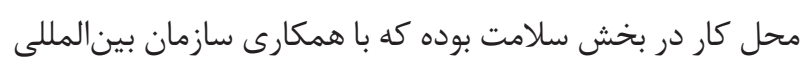

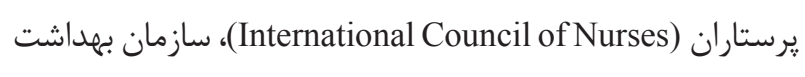
جهانى (World Health Organization)، سازمان بينالمللى كار

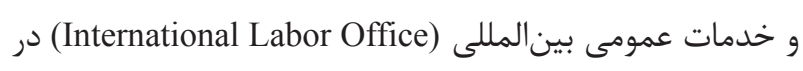

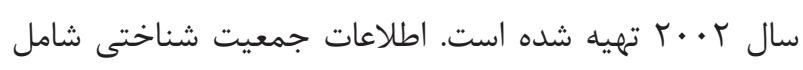

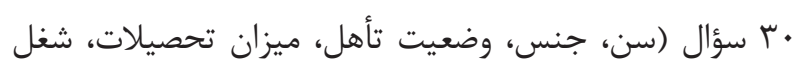

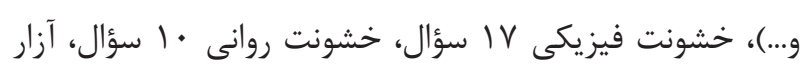

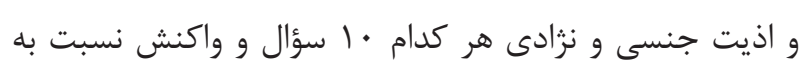
خشونت در قالب أl سؤال و يك سؤال بسته طراحى شن شده است. سؤالات تشريحى يرسشنامه اصلى به صورت سؤال بسته و جواب

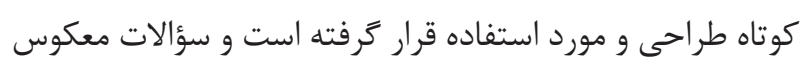
وجود ندارد. روايى صورى و محتوايى آن به تائيد ال 1 نفر از اساتيد

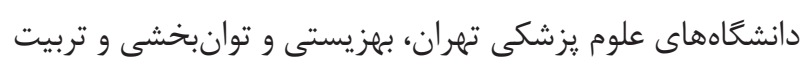
مدرس رسيده است (؟) (؟).

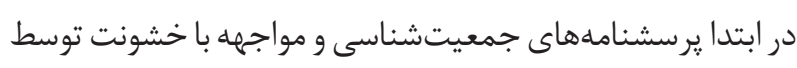

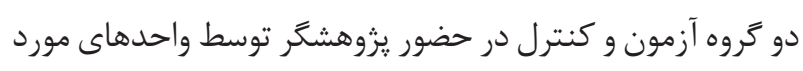
يزوهش تكميل كرديد. جهار جلسه آموزش مديريت خشمه و جهار

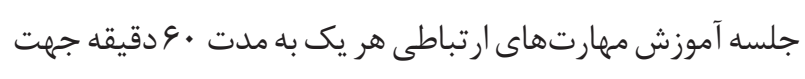

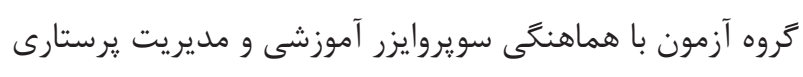

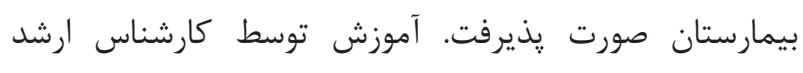

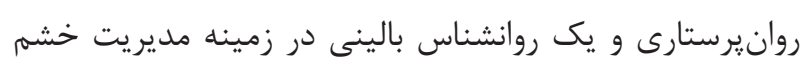

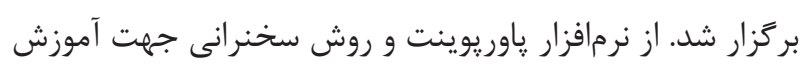

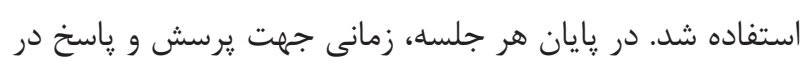



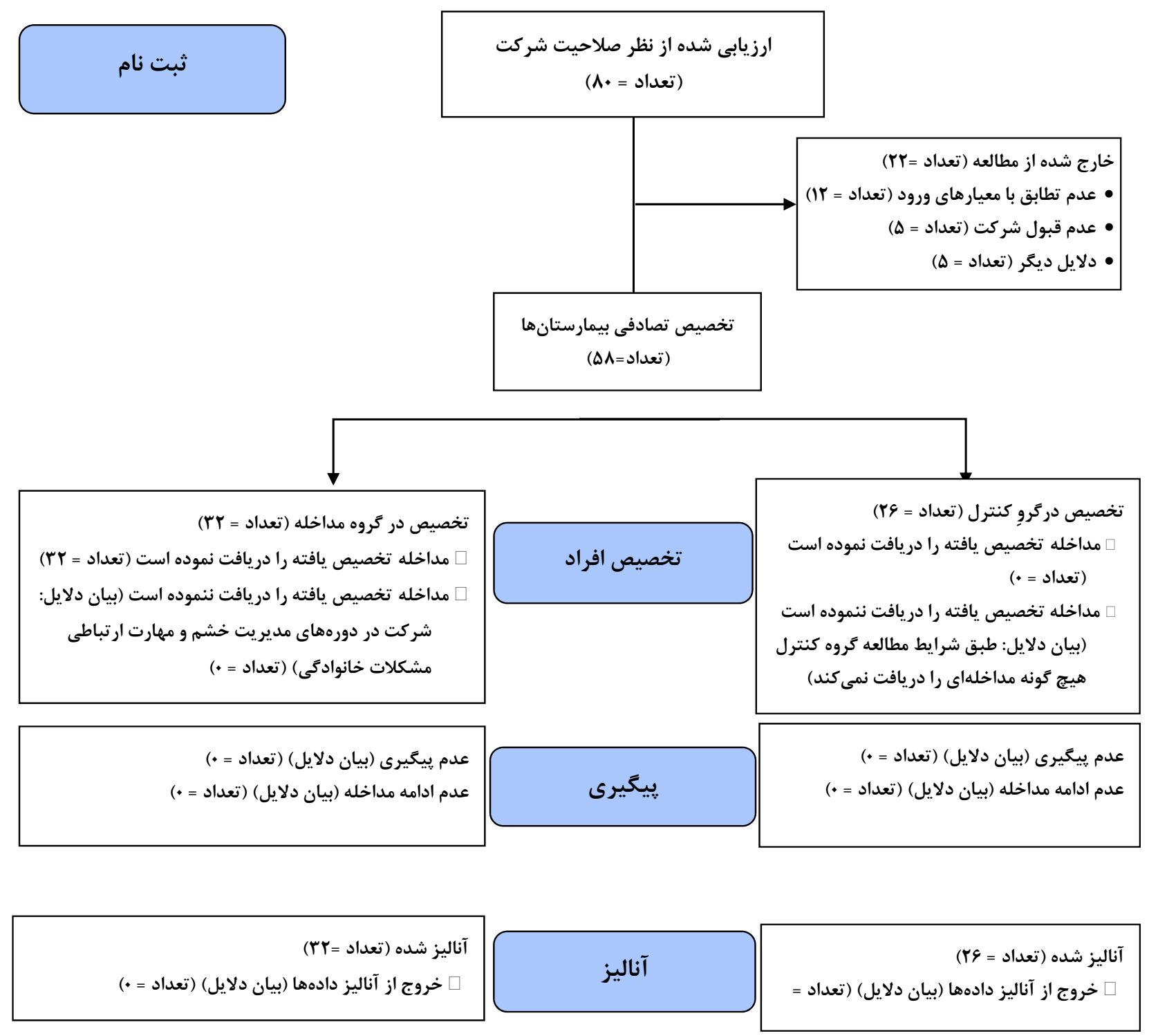

نمودار 1- فرايند انجام مطالعه

همان طور كه در جدول بالا نشان داده شده است دو گروه از نظر جنس، ميزان تحصيلات، رشته تحصيلى، شغل، وضعيت استخدام،

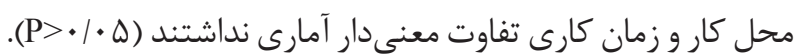

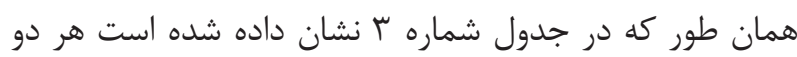

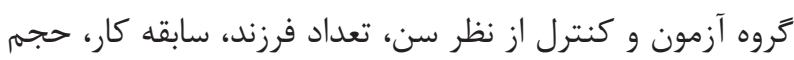

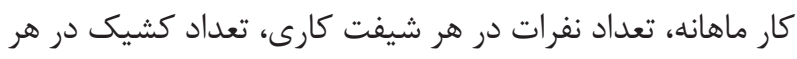

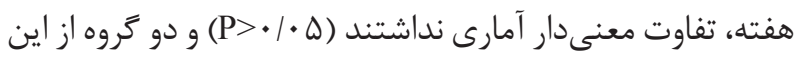
نظر همكَن بودند، وليكن از نظر شيفت كارى تفاوت معنى دارى

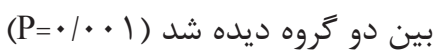
جدول شماره f نشان مىدهد كه دو كروه از نظر رده سنى
قضاوتهاى شخصى خود را وارد يافتههاى مورد مطالعه نكنند، رعايت قوانين نشر از ديكر تعهدات اخلاقى يروهشكَران بود.

يافته ها

يافتهها نشان داد كه اكثريت واحدهاى مورد يزوهش، متأهل، شيعه مذهب و داراى مدرى كارشناسى يرستارى بودند (جدول () ).

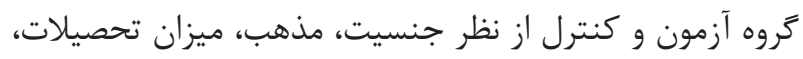
شغل، وضعيت استخدام، محل كار و زمان كار تفاوت معنى مدار

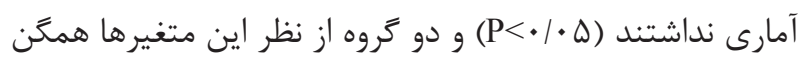

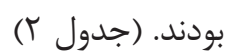


1 هفته در گروه آزمون مربوط به بِيخيرى اقدام خشونت آميز با

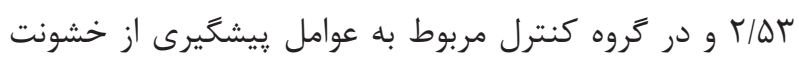

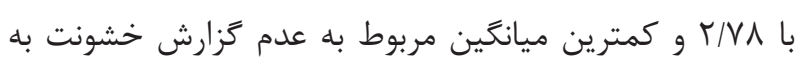

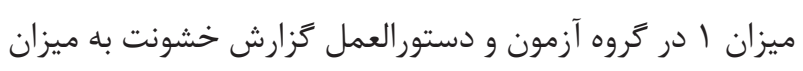

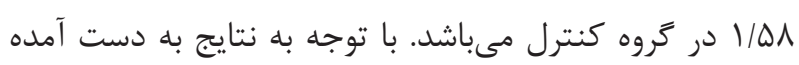

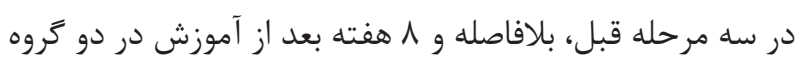

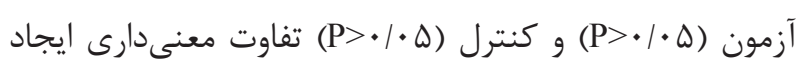

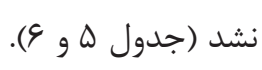

\section{بحث و نتيجه كيرى}

يروهش حاضر با هدف بررسى تأثير آموزش مديريت خشمى و مهارت

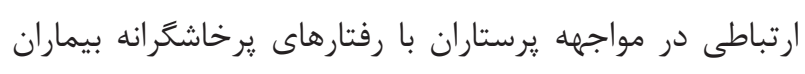

بخش روانيزشكى بيمارستان هاى منتخب نظامى انجام شد.

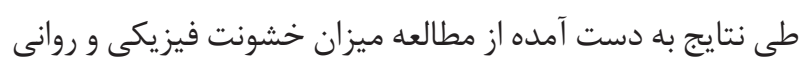
و وقوع خشونت از طرف بيمار در گروه آزمون و كنترل با بيشترين

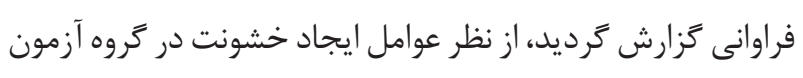

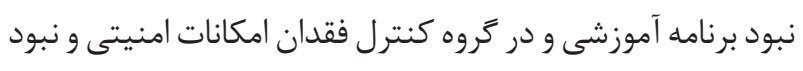

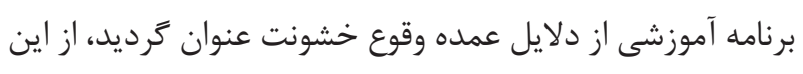

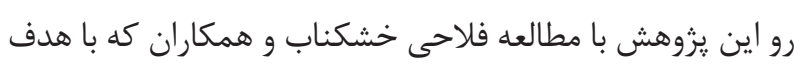
تعيين وضعيت خشونت و عوامل مستعد كننده و ييشخيرى كننده

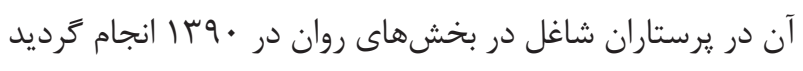

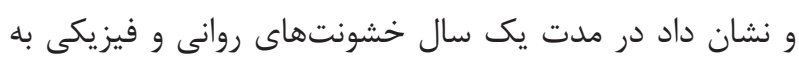

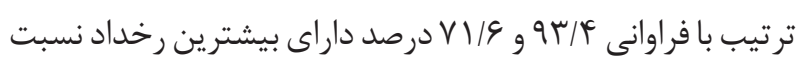
به واحدهاى مورد يزوهش بودند و اغلب خشونتها از طرف بيمار

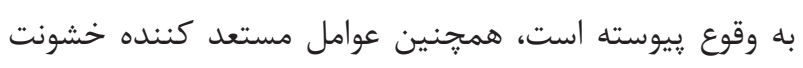
از قبيل تعداد كم نيروى انسانى، عدم وجود امكانات امنيتى، ومدئ،

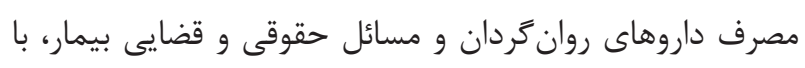
مطالعه حاضر مطابقت دارد و با هم همسو مى باشند، ولى از جهت مدان

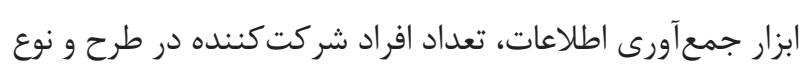
مطالعه متفاوت مىباشد و تنها به بررسى عوامل ايجاد خشونت

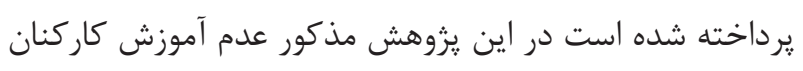

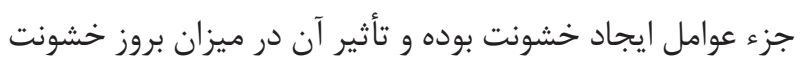

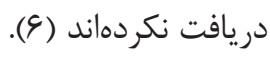

جدول 1- وضعيت جمعيت شناختى واحدهاى مورد يخوهش

\begin{tabular}{|c|c|c|c|}
\hline درصد & تعداد & \multicolumn{2}{|c|}{ متغير - فراوانى } \\
\hline$\Delta \cdot$ & rq & زن & \multirow{2}{*}{ جنس } \\
\hline$\Delta \cdot$ & rq & مرد & \\
\hline vq/r & fq & متأهل & \multirow{4}{*}{ وضعيت تأهل } \\
\hline $1 V / T$ & 1 . & مجرد & \\
\hline $1 / V$ & 1 & بيوه & \\
\hline $1 / V$ & 1 & مطلقه & \\
\hline $94 / 9$ & $\Delta \varphi$ & شيعه & \multirow{2}{*}{ مذهب } \\
\hline$r / \mu$ & $r$ & سنى & \\
\hline $\mid r / 1$ & V & دييلم & \multirow{5}{*}{ تحصيلات } \\
\hline$r / l$ & r & كاردان & \\
\hline$\varphi \Delta / \Delta$ & rᄉ & كارشناس & \\
\hline $1 \mathrm{~V} / \mathrm{r}$ & $1 \cdot$ & كارشناس ارشد & \\
\hline $1 / V$ & 1 & د د & \\
\hline Vq/r. & fq & يرستارى & \multirow{2}{*}{ رشته تحصيلى } \\
\hline$r \cdot / V$. & it & بهيارى & \\
\hline $9 / 9$ & f & سويروايزر & \multirow{4}{*}{ 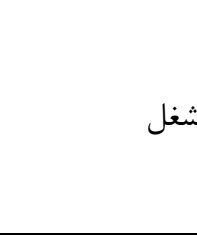 } \\
\hline $9 / 9$ & r & سريرستار & \\
\hline س & $r \Delta$ & يرستار & \\
\hline$r \Delta / 9$ & 10 & بهيار & \\
\hline $9 / 9$ & r & طرحى & \multirow{4}{*}{ وضعيت استخدام } \\
\hline$\wedge 1$ & FV & رسمى & \\
\hline س/ן & $q$ & ييمانى & \\
\hline $1 / V$ & 1 & ساير & \\
\hline
\end{tabular}

بيماران، جنسيت بيماران، مداخله نكَهبان، خشن بودن و يرخطر

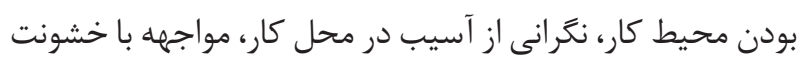

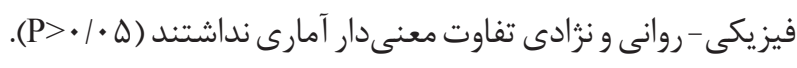

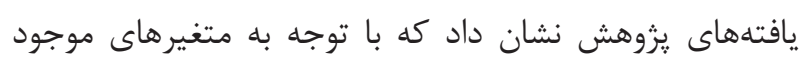

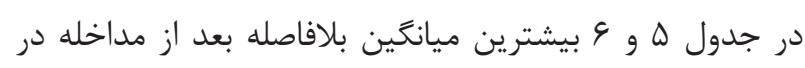

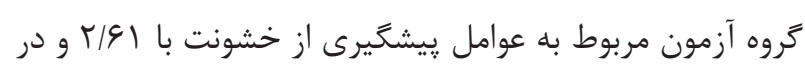

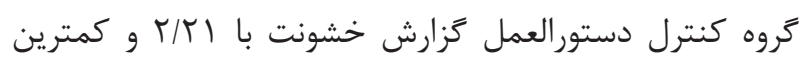

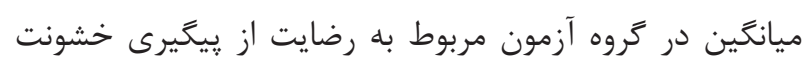
توسط مسئولان و لزوم وجود سيستم مديريتى كزارش خشونت

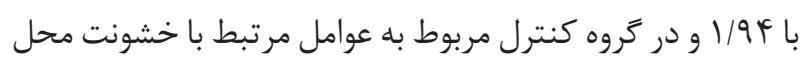

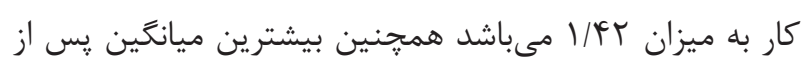


جدول r- مقايسه توزيع فراوانى دو كروه آزمون و كنترل از نظر خصوصيات فردى و شغلى (متغيرهاى كيفى)

\begin{tabular}{|c|c|c|c|c|}
\hline \multirow[b]{2}{*}{ آزمون و سطح معنى دار } & \multicolumn{2}{|c|}{ تروهها } & \multirow{2}{*}{\multicolumn{2}{|c|}{ متغير }} \\
\hline & كنترل & آزمون & & \\
\hline \multirow{3}{*}{ 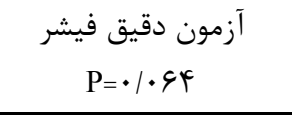 } & & & & \multirow{3}{*}{ جنس } \\
\hline & $9(T / 9)$ & $r \cdot(G T / \Delta)$ & مرد & \\
\hline & $I V(\Phi \Delta / \mathcal{F})$ & $I T(r V / \Delta)$ & زن & \\
\hline \multirow{5}{*}{ 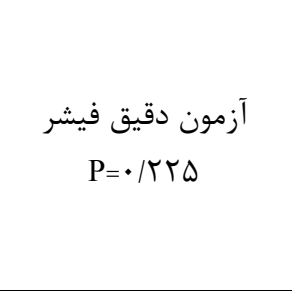 } & $r(V / V)$ & $\Delta(1 \Delta / 9)$ & دييلم & \multirow{5}{*}{ ميزان تحصيلات } \\
\hline & $1(r / \Lambda)$ & $1(r / 1)$ & كاردان & \\
\hline & $10(\Delta V / V)$ & $r r(Y / 9)$ & كارشناس & \\
\hline & $V(Y G / 9)$ & $r(q / \mathcal{F})$ & كارشناس ارشد & \\
\hline & $1(1 / V)$ & · & دكترا & \\
\hline \multirow{2}{*}{$\begin{array}{c}\text { آزمون دقيق فيشر } \\
\text { P= I IV| }\end{array}$} & $r \cdot(G / / \Delta)$ & $r \Delta(\vee \wedge / 1)$ & يرستارى & \multirow{2}{*}{ رشته تحصيلى } \\
\hline & $\varphi(r \mu / l)$ & $V(Y \backslash / \Lambda \Lambda)$ & بهيارى & \\
\hline \multirow{4}{*}{$\begin{array}{c}\text { آزمون دقيق فيشر } \\
\text { P=•/ATV }\end{array}$} & $r(V / V)$ & $r(\varphi / r)$ & سويروايزر & \multirow{4}{*}{ 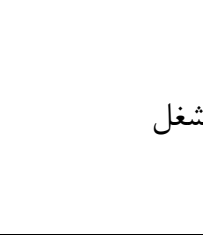 } \\
\hline & $r(V / V)$ & $r(g / \Gamma)$ & سريرستار & \\
\hline & If $(\Delta \Gamma / \Lambda)$ & $r \mid(\Phi \Delta / 9)$ & يرستار & \\
\hline & $\Lambda(\Gamma \cdot / \Lambda)$ & $V(Y / / 9)$ & بهيار & \\
\hline \multirow{4}{*}{ 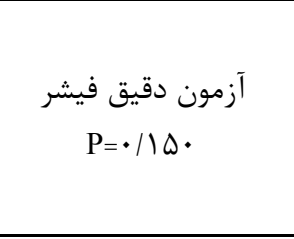 } & · & $F(I Y / \Delta)$ & طرحى & \multirow{4}{*}{ وضعيت استخدام } \\
\hline & $r F(9 T / T)$ & $r(Y / / 9)$ & رسمى & \\
\hline & $r(V / V)$ & $F(I Y / \Delta)$ & قراردادى & \\
\hline & $\cdot$ & $1(r / 1)$ & ساير & \\
\hline \multirow{4}{*}{ 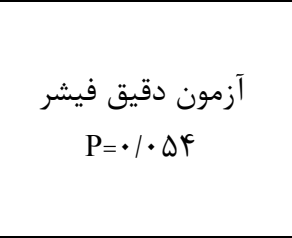 } & $V(r G / 9)$ & $r(9 / 4)$ & درمانگاه & \multirow{4}{*}{ محل كار } \\
\hline & $\cdot$ & $F(I Y / \Delta)$ & اورزانس & \\
\hline & $1(T / \Lambda)$ & $\cdot$ & بخش حاد & \\
\hline & $11(\xi 9 / r)$ & $r \Delta(V \wedge / 1)$ & بخش مزمن & \\
\hline \multirow{3}{*}{$\begin{array}{c}\text { آزمون دقيق فيشر } \\
\text { P=./|| || }\end{array}$} & $19(9 / / 0)$ & rI $(\varepsilon \Delta / \varepsilon)$ & تمام وقت & \multirow{3}{*}{ زمان كارى } \\
\hline & · & $F(\mid r / \Delta)$ & ياره وقت & \\
\hline & $1 \cdot(r \wedge / \Delta)$ & $F(r \mid / q)$ & تمام وقت+ & \\
\hline
\end{tabular}

به عنوان يك مداخله شناخته شده استفاده شده است و كليه

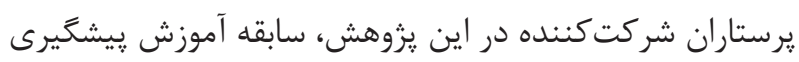

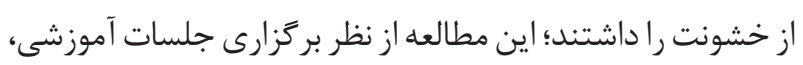

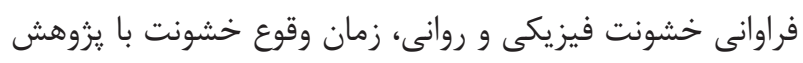
حاضر قرابت دارد و نتايج آن هم راستا با مطالعه اخير بوده و ونشان ونشان

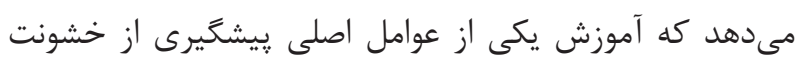

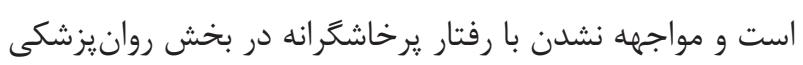

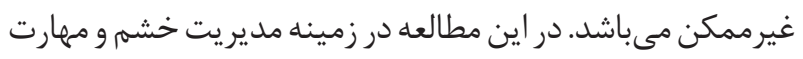

از نظر زمان وقوع خشونت در هر دو كروه آزمون و كنترل بيشترين

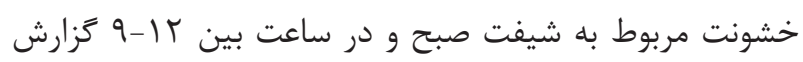

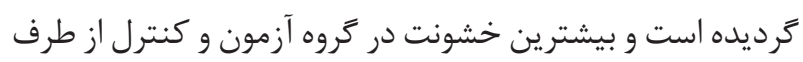

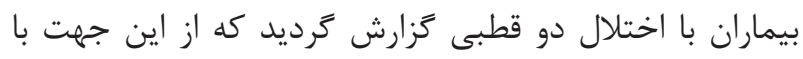
مطالعه ريدينور (Ridenour) و همكاران كه با هدف ارزيابى عوامل كردان

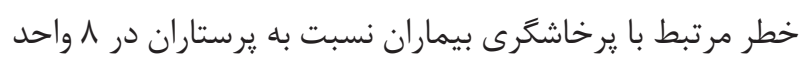

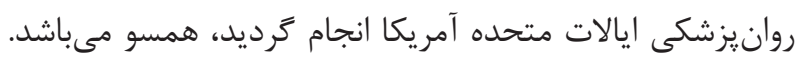

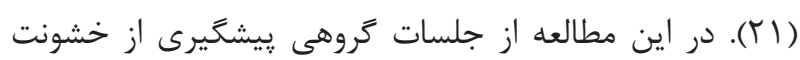


جدول بـ - مقايسه ميانغين و انحر اف معيار دو كروه آزمون و كنترل از نظر خصوصيات فردى و شغلى (متغيرهاى كمى)

\begin{tabular}{|c|c|c|c|}
\hline \multirow{3}{*}{ آزمون و سطح معنى دار } & \multicolumn{2}{|c|}{ تروهها } & \multirow{3}{*}{ متغير } \\
\hline & كنترل & 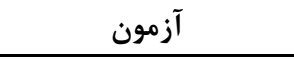 & \\
\hline & ميانگين (انحراف معيار) & ميانگين (انحراف معيار) & \\
\hline 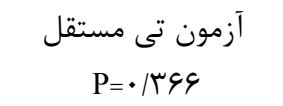 & $(\Delta / q \uparrow) \Gamma q / \Lambda \Delta$ & $(G / Q T) T T / V T$ & سن (سال) \\
\hline 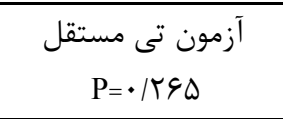 & 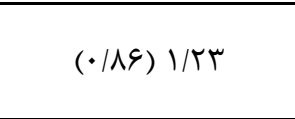 & $(. / 91) 1 / .9$ & تعداد فرزند \\
\hline 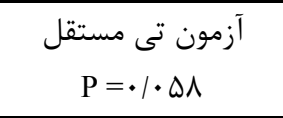 & $(g / T \cdot) T I / T V$ & $(\Lambda / 19) \mid r / \cdot r$ & سابقه كار (سال) \\
\hline $\begin{array}{c}\text { آزمون تى مستقل } \\
P=\text { • } 919\end{array}$ & (GN/VI) & (qr/r人) r & حجم كار (ساعت) \\
\hline 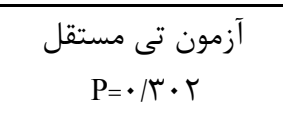 & $(r / F r) r / q r$ & ג & تعداد نفرات در هر شيفت \\
\hline $\begin{array}{c}\text { آزمون تى مستقل } \\
\text { P=•|c4 }\end{array}$ & $(1 / \Upsilon q) \Delta / \cdot \wedge$ & $(1 / \cdots \wedge) \Delta / r r$ & تعداد كشيك \\
\hline
\end{tabular}

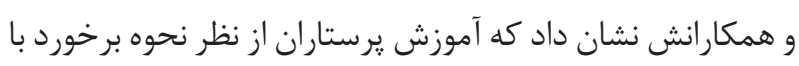

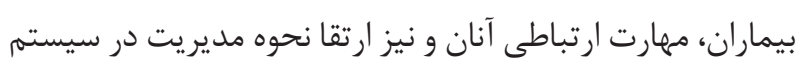

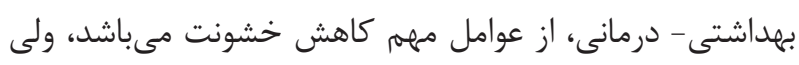

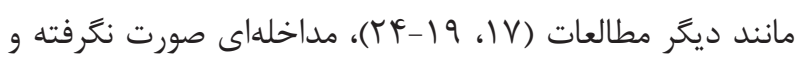

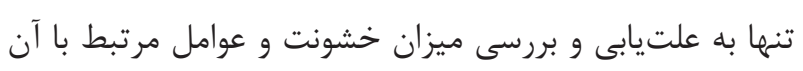

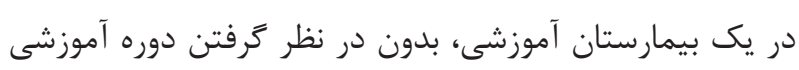

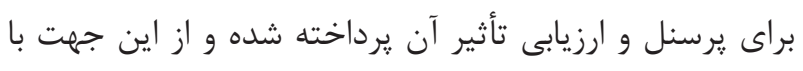
مطالعه اخير متفاوت است. ميانغين رتبهها در خصوص اينكه آيا كسى (منظور مديران يرستارى، حراست، سريرستاران) اقدامى در جهت ييخيرى اقدام خشونتآميزى انجام داده، رضايت يرستاران از بيخيرى موارد

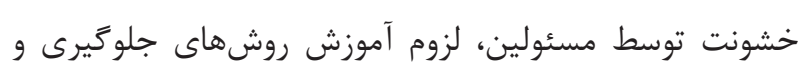
كنترل خشونت، لزوم وجود سيستم مديريتى براى گزارش و كنترل خشونت، هر هند كه در جهت بهبود مواجهه يرستاران با خشونت

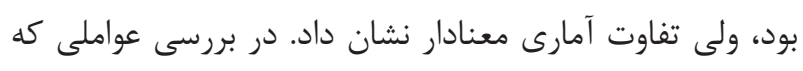
مىتواند از خشونت محل كار ييشخيرى كند ميانگين رتبهها در يس آزمون اول و دوم كاهش نشان داد كه بر خلاف انتظار بود.

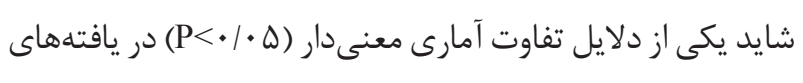

ارتباطى آموزش اختصاصى داده نشده و نحوه جمع آورى اطلاعات و روش كار، نوع بيمارى فرد مهاجم كه بيشتر افرادى با اختلال شخصيت بودهاند با مطالعه حاضر متفاوت مىباشد.

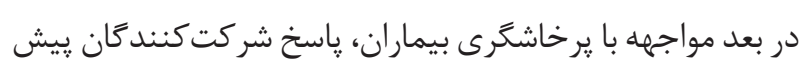
از مداخله در گروه آزمون بيشتر اقدامى نكردهام و در گروه كنترل دعوت مهاجم به آرامش بوده است كه با مطالعه رحمانى و همكاران كه با هدف تعيين فراوانى خشونت، عوامل تعيين كننده و واكنش نسبت به آن در يرستاران شاغل در بخشهاى روانيزشكى در

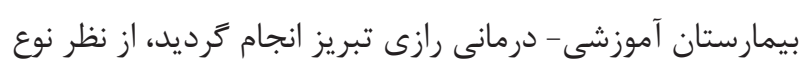
ابزار، محل يزوهش و نتايج به دست آمده و واكنش پيرستاران با مطالعه حاضر همسو مىباشد. همان گَونه كه مشاهده مىشود در اين مطالعه اختصاصاً به بخش روان مراض هرداخته شده كه به مطالعه

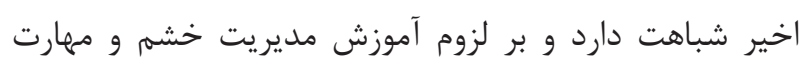
ارتباطى كه منظور نظر مطالعه ما مىباشد تأكيد دارد. عمدهترين عوامل مستعد كننده خشونت به ترتيب پايين بودن تعداد يرستار نسبت به بيمار، برخورد نامناسب گيرسنل يرستارى با بيماران

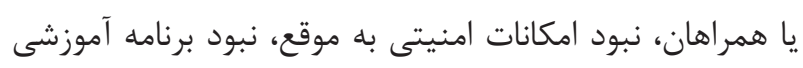

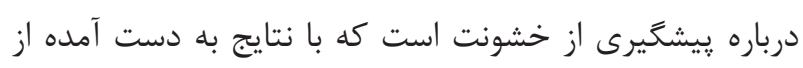

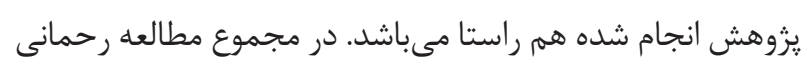


جدول \& - مقايسه توزيع فر اوانى دو كروه آزمون و كنترل از نظر بيماران، شرايط محيط كار، مواجهه با خشونت

\begin{tabular}{|c|c|c|c|c|}
\hline \multirow{3}{*}{ نوع آزمون و سطح معنى دارى } & \multicolumn{2}{|c|}{ كروهها } & & \multirow{3}{*}{ متغير } \\
\hline & كنترل & 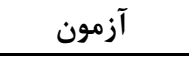 & & \\
\hline & (درصد) تعداد & (درصد) تعداد & & \\
\hline \multirow{2}{*}{ 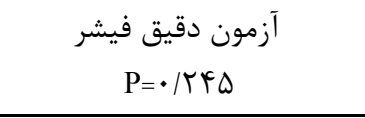 } & $r \varphi(1 \cdots)$ & $r q(9 \cdot 19)$ & 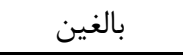 & \multirow{2}{*}{ رده سنى بيماران } \\
\hline & $\cdot$ & $r(9 / 4)$ & بالغ و غير بالغ & \\
\hline \multirow{3}{*}{ 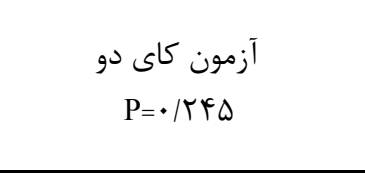 } & Ir $(Y \& / T)$ & $19(\Delta \cdot)$ & 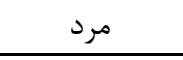 & \multirow{3}{*}{ جنسيت بيماران } \\
\hline & $V(T G / 9)$ & $\Delta(\mid \Delta / 9)$ & 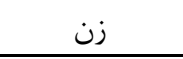 & \\
\hline & $V(T \xi / 9)$ & $\|(\Psi \mathcal{F} / \mathcal{F})$ & هردو جنس & \\
\hline \multirow{5}{*}{$\begin{array}{c}\text { آزمون دقيق فيشر } \\
P=\text { P }=\text { V }\end{array}$} & $1 \cdot(r \wedge / \Delta)$ & · & هميشه & \multirow{5}{*}{ مداخله نتخهبان } \\
\hline & $1 \cdot(r \wedge / \Delta)$ & I (T/T) & اكثر اوقات & \\
\hline & $r(11 / \Delta)$ & I & معمولاً & \\
\hline & $r(V / V)$ & l & كاهى اوقات & \\
\hline & I (r/A) & $\cdot$ & هيج وقت & \\
\hline \multirow{5}{*}{ 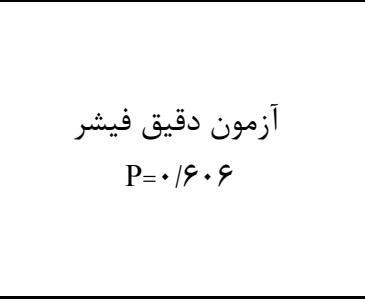 } & $f\left(\mid \Delta / T^{\mathcal{F}}\right)$ & $q(T \wedge / 1)$ & هميشه & \multirow{5}{*}{ محيط كار خشن } \\
\hline & $11(\mathcal{F} / \mathrm{K})$ & IT $(r V / Q)$ & اكثر اوقات & \\
\hline & $\Delta(19 / T)$ & $r(9 / 4)$ & معمولاً & \\
\hline & $G(Y T / I)$ & $V(Y) / 9)$ & كاهى اوقات & \\
\hline & $\cdot$ & $1(\Gamma / 1)$ & هيج وقت & \\
\hline \multirow{4}{*}{ 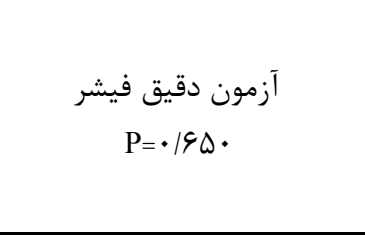 } & $1 \cdot(r \wedge / \Delta)$ & $11(T Y / F)$ & هميشه & \multirow{4}{*}{ محيط كار يرخطر } \\
\hline & $11(F / T)$ & $11(K \mathcal{F} / \mathcal{F})$ & اكثر اوقات & \\
\hline & $r(11 / \Delta)$ & $\Lambda(T \Delta)$ & معمولاً & \\
\hline & $r(V / V)$ & $r(\mathcal{G / T})$ & عاهى اوقات & \\
\hline \multirow{5}{*}{$\begin{array}{c}\text { آزمون دقيق فيشر } \\
\text { P=•/VF }\end{array}$} & $\Lambda(\Gamma \cdot \mid \Lambda)$ & $\Lambda(T \Delta)$ & هميشه & \multirow{5}{*}{ نَرانى از خطر آسيب } \\
\hline & $V(Y \& / 9)$ & $11(T / F)$ & اكثر اوقات & \\
\hline & $f(\mid Q / f)$ & $r(q / 4)$ & معمولاً & \\
\hline & $V(\Gamma \varepsilon / 9)$ & $V(r \Delta)$ & عاهى اوقات & \\
\hline & $\cdot$ & $r(\varepsilon / \Gamma)$ & هيج وقت & \\
\hline \multirow{2}{*}{ 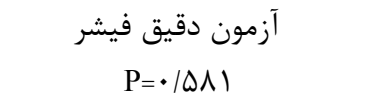 } & $V(\Gamma \varepsilon / 9)$ & $\|(\Psi \mathcal{F} / \mathcal{F})$ & خير & \multirow{2}{*}{ مواجهه با خشونت فيزيكى } \\
\hline & $r \Delta(৭ \& / T)$ & $r \cdot(9 \mu / \Lambda)$ & بله & \\
\hline \multirow{2}{*}{$\begin{array}{c}\text { آزمون دقيق فيشر } \\
\text { P=1 }\end{array}$} & $r(V / V)$ & $r(q / F)$ & خير & \multirow{2}{*}{ مواجهه با خشونت روانى } \\
\hline & $T F(q Y / T)$ & rq $(9 \cdot 19)$ & بله & \\
\hline \multirow{2}{*}{$\begin{array}{c}\text { آزمون دقيق فيشر } \\
\text { P=1 }\end{array}$} & rD $(94 / T)$ & $r \cdot(9 \mu / \Lambda)$ & خير & \multirow{2}{*}{ مواجهه با خشونت نزادى } \\
\hline & $1(r / \Lambda)$ & $r(\varphi / r)$ & بله & \\
\hline
\end{tabular}

يقيخيرى اقدام خشونتآميز توسط مسئولان، لزوم آموزش روشهاى مهارت ارتباطى و مديريت خشهم باشد.

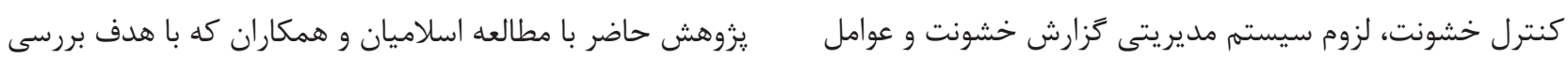

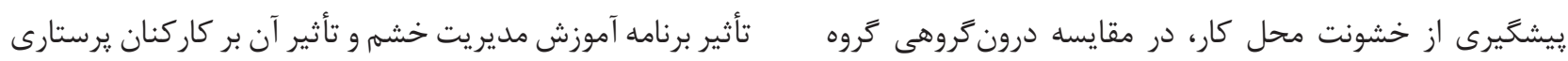

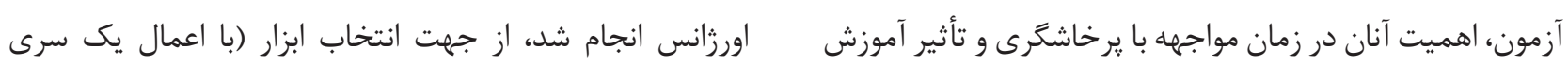


جدول هـ - مقايسه ميانكَين رتبه هاى تروه آزمون بيش از مداخله، بلافاصله بعد از مداخله و 1 هفته بعد از مداخله

\begin{tabular}{|c|c|c|c|c|}
\hline \multirow{2}{*}{ سطح معنى دارى نوع آزمون } & \multicolumn{3}{|c|}{ ميانگين رتبهها } & \multirow{2}{*}{ مرحله } \\
\hline & ^ هفته بعد از مداخله & بلافاصله بعد از مداخله & يِيش از مداخله & \\
\hline 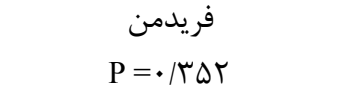 & $r / I V$ & r & l/Ar & واكنش به خشونت \\
\hline $\begin{array}{c}\text { فريدمن } \\
\mathrm{P}=\cdot \text { • }\end{array}$ & 1 & $r / I V$ & T/A & عدم زَارش خشونت \\
\hline 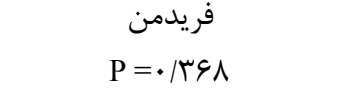 & $1 / 91$ & $1 / 91$ & $r / r$ & دستورالعمل گزارش خشونت \\
\hline $\begin{array}{l}\text { فريدمن } \\
\mathrm{P}=\text {. }\end{array}$ & T/DT & $1 / \Lambda \Lambda$ & $1 / 09$ & ييخيرى اقدام خشونتآميز \\
\hline 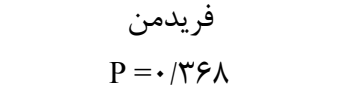 & $1 / 1 \cdot$ & $r / l \cdot$ & $r / l \cdot$ & فرد ييخيرى كننده \\
\hline $\begin{array}{l}\text { فريدمن } \\
P=\text {. }\end{array}$ & $r / T \Delta$ & $1 / 94$ & $1 / V 1$ & رسئيولان \\
\hline $\begin{array}{c}\text { فريدمن } \\
P=/ / 1\end{array}$ & l/Ar & $r / \mu \cdot$ & $1 / \Lambda \Lambda$ & عوامل مرتبط با خشونت محل كار \\
\hline $\begin{array}{l}\text { فريدمن } \\
\mathrm{P}=\text {. }\end{array}$ & $r / \Delta \cdot$ & $r / \Delta \cdot$ & 1 & آموزش كنترل خشونت \\
\hline 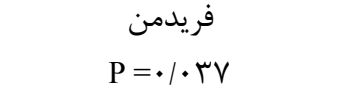 & $1 / 19$ & $T / \cdot T$ & $r / \cdot 9$ & لزوم آموزش روشهاى كنترل خشونت \\
\hline $\begin{array}{c}\text { فريدمن } \\
P=\cdot / \cdot 1\end{array}$ & $1 / 1 \cdot$ & $1 / 94$ & $T / T V$ & خشون وجود سيستم مديريتى تزارش \\
\hline $\begin{array}{c}\text { فريدمن } \\
\mathrm{P}=\cdot \mid \mathrm{V} \cdot \mathrm{V}\end{array}$ & $r / \Lambda$ & $r / \cdot r$ & $1 / 19$ & نحوه جبران خسارت يرستاران \\
\hline 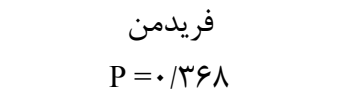 & $1 / 90$ & r & $r / \cdot \Delta$ & شاهد وقوع خشونت \\
\hline 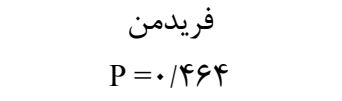 & T/IT & $T / \cdot T$ & $1 / \wedge 9$ & عوامل ايجاد خشونت \\
\hline $\begin{array}{l}\text { فريدمن } \\
\mathrm{P}=\end{array}$ & $1 / 09$ & $r|9|$ & $1 / \Lambda \cdot$ & عوامل پيشگيرى از خشونت \\
\hline
\end{tabular}

است، با مطالعه حاضر متفاوت مىباشد. يافتههاى حاصل از مطالعه استفان گَى (Stephane Guay) و همكاران تحت عنوان ارزيابى يك برنامه آموزشى براى جلوخيرى

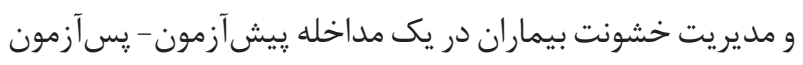
با هدف بررسى تأثير برنامه آموزشى امعا در كاركنان مراكز $1+1$ روانيزشكى بود، نشان داد سطح درى شده اشكال مختلف خشونت و ميزان اضطراب مراقبين تحت مطالعه به طور معنى دار در تمام
تغييرات) و نتايج به دست آمده همسو مىباشد و نشان مى دهد كه آموزش مىتواند بر جنبه هاى نكرش افراد، نحوه مديريت رفتارهاى خشونتآميز در برخورد با شرايط خشونتآميز تأثير مثبت داشته باشد (Tr)، ولى از اين جهت كه مطالعه بر روى يرستاران شاغل

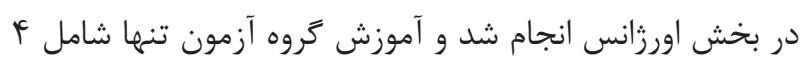
جلسه •و دقيقهاى جهت مديريت خشم انجام گرديده و به تأثير آموزش مهارت ارتباطى و تأثير آن در مواجهه با خشونت نيرداخته 


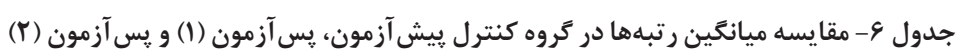

\begin{tabular}{|c|c|c|c|c|}
\hline \multirow{2}{*}{ سطح معنىدارى و نوع آزمون } & \multicolumn{3}{|c|}{ ميانگين رتبهها } & \multirow{2}{*}{ مرحله } \\
\hline & يست تست (Y) & يست تست (1) & ييش آزمون & \\
\hline $\begin{array}{c}\text { فريدمن } \\
\text { P=. }\end{array}$ & $r / V T$ & $1 / \Delta T$ & $1 / V \Delta$ & واكنش به خشونت \\
\hline $\begin{array}{c}\text { فريدمن } \\
\text { P=. }\end{array}$ & $r / 9 V$ & $1 / V \cdot$ & $1 / 9$ & عدم ززارش خشونت \\
\hline $\begin{array}{c}\text { فريدمن } \\
\text { P=. }\end{array}$ & $1 / \Delta \Lambda$ & $T / \pi)$ & $T / T)$ & دستورالعمل گزارش خشونت \\
\hline 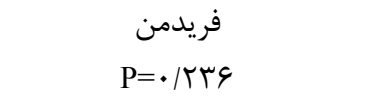 & I/AV & $r / l \cdot$ & $T / \cdot F$ & 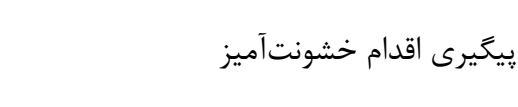 \\
\hline 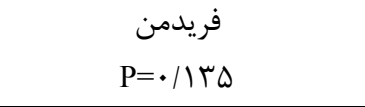 & $r / \Delta \cdot$ & $1 / V \Delta$ & $1 / V \Delta$ & فرد يیيَيرى كننده \\
\hline $\begin{array}{c}\text { فريدمن } \\
\mathrm{P}=\text { ف V V }\end{array}$ & $r / \cdot F$ & r & $1 / 99$ & رضايت از ييخيرى خشونت توسط مسئولان \\
\hline $\begin{array}{c}\text { فريدمن } \\
\text { P=. }\end{array}$ & r & $1 / 4 T$ & $1 / \Delta \Lambda$ & عوامل مرتبط با خشونت محل كار \\
\hline 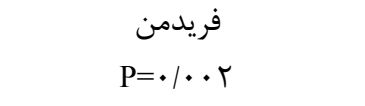 & $1 / V V$ & $r / I T$ & $T / 1 T$ & آموزش كنترل خشونت \\
\hline $\begin{array}{c}\text { فريدمن } \\
\mathrm{P}=\text { فو }\end{array}$ & $T / 1 Q$ & $1 / 94$ & 1/9r & لزوم آموزش روشهاى كنترل خشونت \\
\hline 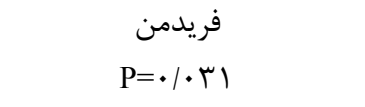 & $T / T V$ & $1 / \Lambda 1$ & $1 / 9 r$ & لزوم وجود سيستم مديريتى گزارش خشونت \\
\hline $\begin{array}{c}\text { فريدمن } \\
\mathrm{P}=\text { |ع }\end{array}$ & $T / T)$ & r & $1 / \vee 9$ & نحوه جبران خسارت برستاران \\
\hline 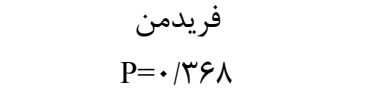 & $1 / \wedge \Delta$ & $r / \cdot \varphi$ & $r / l \cdot$ & شاهد وقوع خشونت \\
\hline 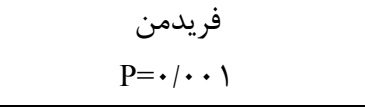 & 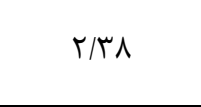 & $1 / \Delta 9$ & $r / \cdot G$ & 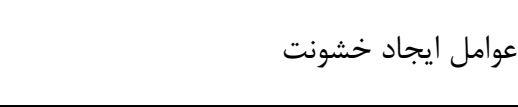 \\
\hline 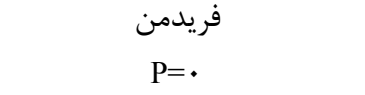 & T/VA & 1/VG & $1 / 49$ & عوامل بيشخيرى از خشونت \\
\hline
\end{tabular}

يزوهش مشاهده مىشود اجراى يك برنامه آموزشى تا جه ميزان در كاهش رفتار يرخاشگرانه بيماران و افزايش كارايى كاركنان و و جلوكيرى از مشكلات روانشناختى آنان مؤثر است كه از اين جهت با مطالعه اخير همسو مىباشد و تفاوت آن با مطالعه حاضر نوع آموزش ارائه شده، ابزار استفاده شده و عدم تأكيد آن بر يرستاران شاغل در بخش روانيزشكى است. در مطالعه يلديز (Yeldiz) و همكاران تحت عنوان تأثير مديريت
زمانهاى اندازهخيرى كاهش يافته و اعتماد به نفس در برابر فرد

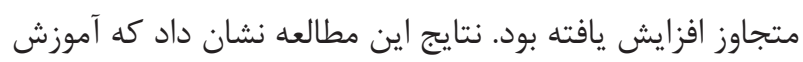

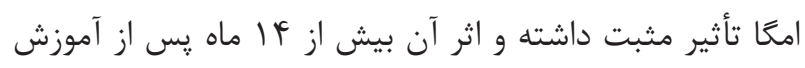

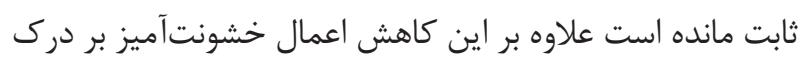
كاركنان از كار خود تأثير داشته و در نتيجه كيفيت ارتباط بين ارائه دهنده خدمت و بيمار افزايش مىيابد و تعهد و انخيزه، خطر رها كردن كار را كاهش مى 
خشم در ارائهدهند أن اين گَونه خدمات كه از آموزشهاى ناكافى

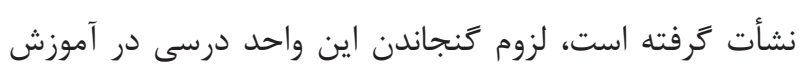

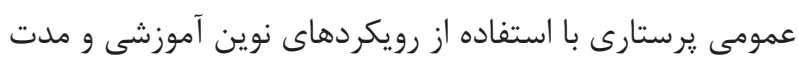
طولانىتر آموزش ضرورى به نظر مىرسد.

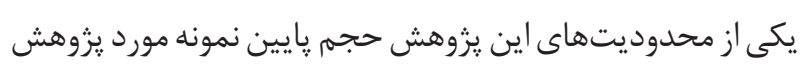

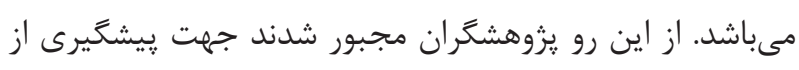

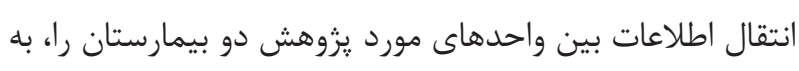

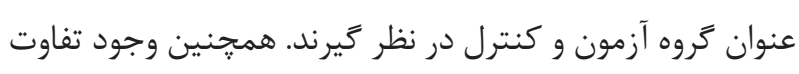
معنى دار بين دو گروه از نظر شيفت كارى از محدوديتهاى ائر اين

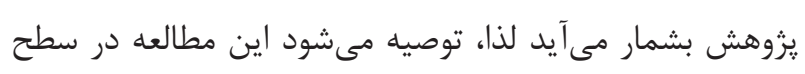
وسيعتر در ديكر مراكز تخصصى روانيزشكى انجام گردد تا بتواند

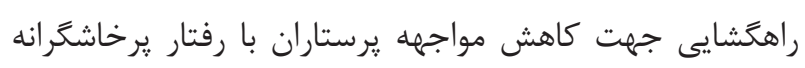
بيماران، كاهش فرسودگى شغلى و آسيب روحى و روانى در

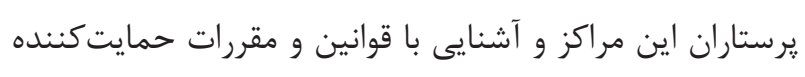
از آنان در صورت آسيب و مواجهه با برخاشكرى إنى باشد.

\section{تشكر و قدردانى}

اين مقاله بركرفته از پايانامه كارشناسى ارشد روانى رانيرستارى

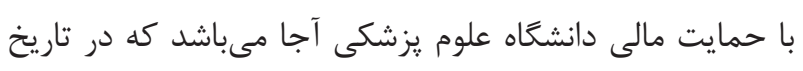

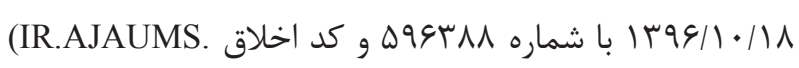

$$
\text { REC.I ب9.1... ) }
$$

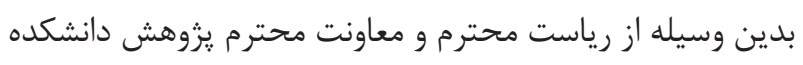

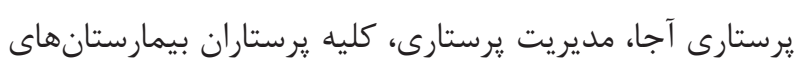

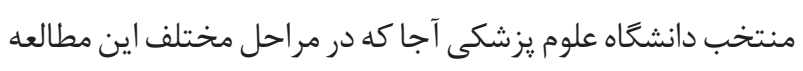
همكارى صادقانه داشتند تشكر و قدردانى مىنمايمه.

تضاد منافع بدين وسيله نويسندكان تصريح مىنمايند كه هيجَّونه تضاد منافعى در خصوص يزوهش حاضر وجود ندارد.
خشم و مهارت ارتباطى بر مواجهه با خشونت يرسنل اورزانس كه با هدف تعيين تأثير مديريت خشمه و مهارت ارتباطى كار كنان بخش منش

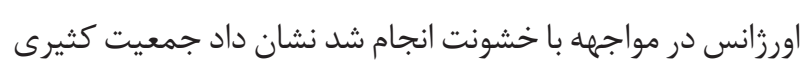
از شركت كنندكان در طول زمان مورد خشونت قرار كرفته بودند؛

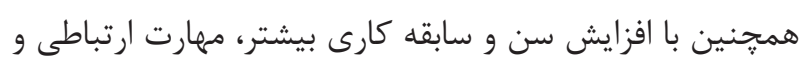

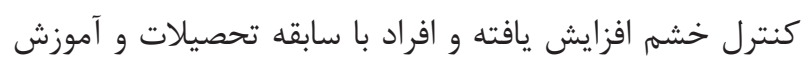
بيشتر مديريت خشم و مهارت ارتباطى، ميانكين كنترل خشم الاته

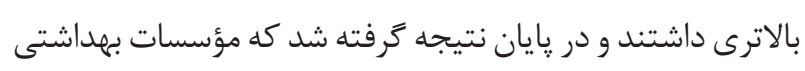

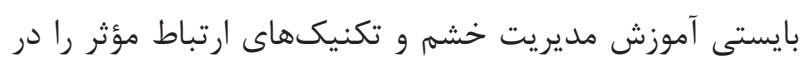

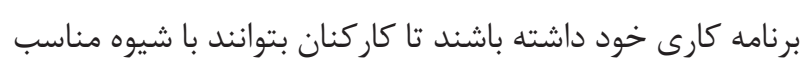

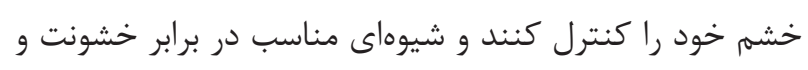

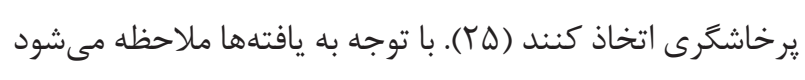

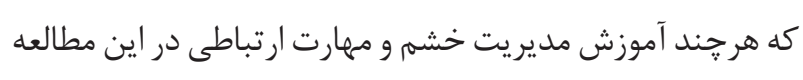

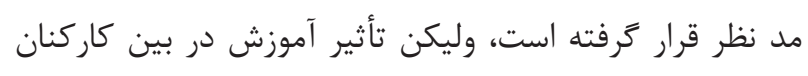
اورزانس بررسى شده و مختص يرستاران نبوده و به مواجهه ير برسنل

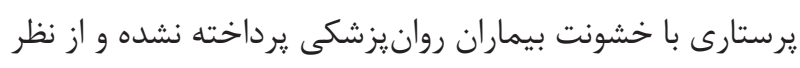

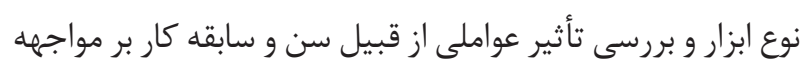
با خشونت، با يزوهش حاضر متفاوت است، ولى از نظر نوع مطالعه

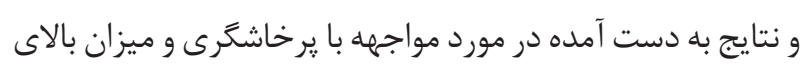
خشونت كلامى با مطالعه حاضر همسو مىباشد.

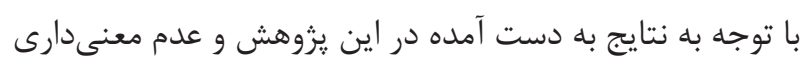

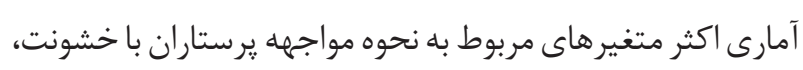

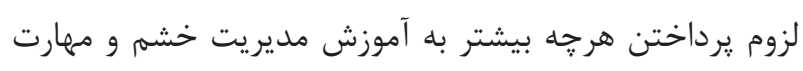

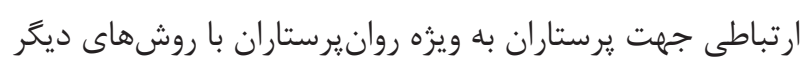
آموزشى توصيه مى ارتردد.

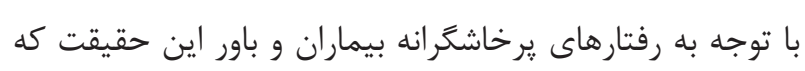

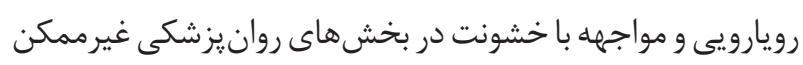

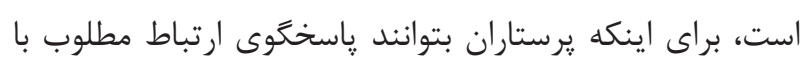

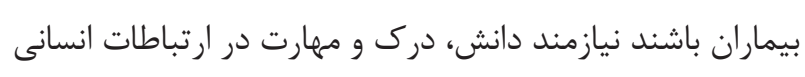

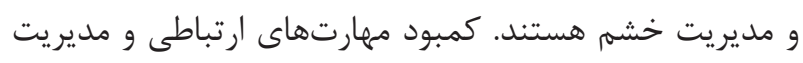




\section{References}

1- Mohr WK. Psychiatric-mental health nursing. 7th ed. Philadelphia: Wolters Kluwer Health/Lippincott Williams \& Wilkins; 2009.

2- Nijman HLI, Muris P, Merckelbach HLGJ, Palmstierna T, Wistedt $\mathrm{B}$, Vos AM, et al. The staff observation aggression scale-revised (SOAS-R). Aggressive Behavior. 1999;25(3):197-209. DOI: 10.1002/(sici)1098-2337(1999)25:3<197::Aid-ab4>3.0.Co;2-c

3- Serper MR, Goldberg BR, Herman KG, Richarme D, Chou J, Dill $\mathrm{CA}$, et al. Predictors of aggression on the psychiatric inpatient service. Compr Psychiatry. 2005;46(2):121-7. DOI: 10.1016/j. comppsych.2004.07.031 PMID: 15723029

4- Cezar ES, Marziale MH. [Occupational violence problems in an emergency hospital in Londrina, Parana, Brazil]. Cad Saude Publica. 2006;22(1):217-21. DOI: 10.1590/s0102311x2006000100024 PMID: 16470300

5- Dean AJ, Gibbon P, McDermott BM, Davidson T, Scott J. Exposure to aggression and the impact on staff in a child and adolescent inpatient unit. Arch Psychiatr Nurs. 2010;24(1):15-26. DOI: 10.1016/j.apnu.2009.01.002 PMID: 20117685

6- Fallahi Khoshknab M, Tamizi Z, Ghazanfari N. [Workplace violence status, vulnerable and preventive factors among nurses working in psychiatric wards]. J Heal Prom Manage. 2013;2(3):716.

7- Onwumere J, Grice S, Garety P, Bebbington P, Dunn G, Freeman D, et al. Caregiver reports of patient-initiated violence in psychosis. Can J Psychiatry. 2014;59(7):376-84. DOI: 10.1177/070674371405900705 PMID: 25007421

8- Khoftehdel M, Zangooei H, Mohammadzadeh R. [Examination of being Effectiveness of anger managment teaching on aggression and aggressive thoughts of soldiers in one of Khorasan Razavi province,s military unit]. 1th International Conference \& 2th National Conference on Modern Research in the Humanities; Tehran2015.

9- Ramezani T. [Nurses' experiences of occupational aggression in the psychiatric wards: Phenomenology approach]. J Fund Men Heal. 2012;13(4):314-27.

10- Esmaeilpour Bandboni M. [Violence against emergency nurses, prevalence and prevention ]: Tehran University of Medical Sciences; 2011.

11- Anderson A, West SG. Violence against mental health professionals: when the treater becomes the victim. Innov Clin Neurosci. 2011;8(3):34-9. PMID: 21487544

12- Boyd MA. Psychiatric nursing: Contemporary practice. 3 th ed ed. Philadelphia: lippincott Williams \& wilkins; 2005.

13- Ferri P, Silvestri M, Artoni C, Di Lorenzo R. Workplace violence in different settings and among various health professionals in an Italian general hospital: a cross-sectional study. Psychol Res Behav Manag. 2016;9:263-75. DOI: 10.2147/PRBM.S114870 PMID: 27729818
14- Rostami H, Golchin M, Mirzaei A. [Evaluation of Communication Skills of Nurses from Hospitalized Patients' Perspective]. J Urmia Nurs Mid Fac. 2012;10(1):27-34.

15- Babaei N, Rahmani A, Mohajjel-Aghdam A, Zamanzadeh V, Dadashzadeh A, Avazeh M. [Workplace violence against nurses from the viewpoint of patients]. Iran J Psyc Nurs 2014;2(1):43-54.

16- Safavi M, Ghasemi Panjah S, Fesharaki M, Esmaeilpour Bandboni M. Communication Skills and Its Related Factors in Guilans Teaching Hospitals' Nurses 94. Scientific Journal of Hamedan Nursing and Midwifery Faculty. 2016;24(1):50-7. DOI: 10.20286/ nmj-24017

17- Sadeghi Shermeh M, Amiri H, Karimi Zarchi A, Bahari F, Binesh A. Effectiveness of solution-focused communication training (SFCT) in nurses' communication skills. J Mil Med. 2013;14(4):279-86.

18- World Medical A. World Medical Association Declaration of Helsinki: ethical principles for medical research involving human subjects. JAMA. 2013;310(20):2191-4. DOI: 10.1001/ jama.2013.281053 PMID: 24141714

19- Khodadadi E, Ebrahimi H, Moghaddasian S, Babapour J. The effect of communication skills training on quality of care, selfefficacy, job satisfaction and communication skills rate of nurses in hospitals of tabriz, iran. J Caring Sci. 2013;2(1):27-37. DOI: 10.5681/jcs.2013.004 PMID: 25276707

20- Najafi F, Fallahi-Khoshknab M, Dalvandi A, Ahmadi F, Rahgozar M. Workplace violence against Iranian nurses: A systematic review. J Heal Prom Manage. 2014;3(2):72-85.

21- Ridenour M, Lanza M, Hendricks S, Hartley D, Rierdan J, Zeiss $\mathrm{R}$, et al. Incidence and risk factors of workplace violence on psychiatric staff. Work. 2015;51(1):19-28. DOI: 10.3233/WOR141894 PMID: 24894691

22- Rahmani F, Ebrahimi H, Asghari E. Workplace Violence, its Determinants and Reaction toward it Perceived by Nurses Working in Psychiatric Wards: A Cross-Sectional Study. Iran Journal of Nursing. 2015;28(97):1-10. DOI: 10.29252/ijn.28.97.1

23- Eslamian J, Fard SH, Tavakol K, Yazdani M. The effect of anger management by nursing staff on violence rate against them in the emergency unit. Iran J Nurs Midwifery Res. 2010;15(Suppl 1):337-42. PMID: 22069408

24- Guay S, Goncalves J, Boyer R. Evaluation of an Education and Training Program to Prevent and Manage Patients' Violence in a Mental Health Setting: A Pretest-Posttest Intervention Study. Healthcare (Basel). 2016;4(3). DOI: 10.3390/healthcare4030049 PMID: 27490582

25- Yildiz Das G, Aydin Avci I. The effect of anger management levels and communication skills of Emergency Department staff on being exposed to violence. Med Glas (Zenica). 2015;12(1):99104. PMID: 25669345 